\title{
BỆNH U HẠT MẠN TÍNH HIẾM GẶP: BÁO CÁO CA BẸNH
}

\author{
Nguyễn Thị Ngọc Hồng ${ }^{1, \bigotimes}$, Nguyễn Thị Việt Hà ${ }^{1,2}, N$ guyễn Thanh Bình ${ }^{1,2}$, \\ Trần Thị Thúy Hạnh', Đặng Thúy Hà2, Phạm Thị Thanh Nga², \\ Lương Thị Minh², Nguyễn Thị Thu Trang², Lê Thị Hương² \\ ${ }^{1}$ Trường Đại học Y Hà Nội \\ ²Bệnh viện Nhi Trung ương
}

Bệnh u hạt mạn tính (Chronic Granulomatous Disease - CGD) là bệnh lý di truyền hiếm gặp, với biểu hiện lâm sàng là các đợt nhiễm trùng nặng, tái diễn gây ra bởi vi khuẩn và nấm, do khiếm khuyết khả năng thực bào của bạch cầu trung tính và đại thực bào. Chúng tôi mô tả một trường hợp bệnh nhân CGD với biểu hiện lâm sàng và cận lâm sàng giống với bệnh Crohn như tiêu chảy kéo dài, áp xe cạnh hậu môn và tiền sử có nhiều đợt nhiễm khuẩn nặng. Bệnh nhân luôn có số lượng bạch cầu máu ngoại vi cao. Xét nghiệm đánh giá chức năng bạch cầu hạt (test $D H R$ ) cho thấy chức năng bạch cầu hạt giảm nặng và được khẳng định bằng xét nghiệm giải trình tự gen phát hiện đột biến gen CYBB vị trí c.217C>T (p.Arg73Stp) trên NST giới tính X, quy định tổng hợp protein gp91phox là một cấu phần quan trọng của enzyme NADPH oxidase. Bệnh nhân được điều trị thành công với kháng sinh tĩnh mạch, điều trị dụ̣ phòng nhiễm khuẩn và nấm suốt đời. Đây là trường hợp bệnh hiếm và khó chẩn đoán. Triệu chứng gần giống với các bệnh lý nhiễm khuẩn khác đặc biệt là bệnh Crohn trong chuyên khoa tiêu hóa nên cần phân biệt và chẩn đoán để có phác đồ và kế hoạch điều trị phù hợp.

Từ khóa: bệnh u hạt mạn tính (CGD), bệnh Crohn, nhiễm khuẩn tái diễn.

\section{I. ĐẠT VẤN ĐÉ}

Bệnh u hạt mạn tính (Chronic Granulomatous Disease - CGD) là một bệnh suy giảm miễn dịch nguyên phát di truyền, làm tăng khả năng nhạy cảm của cơ thể với các bệnh nhiễm trùng do một số vi khuẩn và nấm. Bệnh do giảm chức năng bạch cầu hạt trung tính làm cho cơ thể không chống lại được các vi khuẩn thông thường dẫn tới nhiễm trùng nặng và tái diễn ở nhiều cơ quan của cơ thể. Tỷ lệ lưu hành bệnh khoảng 1/200.000 - 1/250.000 trẻ sinh ra sống tại Mỹ, Châu Âu. ${ }^{1}$ Các triệu chứng lâm sàng thường xuất hiện sớm ở giai đoạn sơ sinh, một số phân nhóm hiếm gặp xảy ra ở giai đoạn muộn hơn. 43\% bệnh nhân CGD do

Tác giả liên hệ: Nguyễn Thị Ngọc Hồng

Đại học Y Dược Thành phố Hồ Chí Minh

Email: nguyenthingochong94@gmail.com

Ngày nhận: 19/04/2021

Ngày được chấp nhận: 26/05/2021 đột biến gen trên NST X và khoảng $11 \%$ bệnh nhân CGD do đột biến gen trên NST thường có biểu hiện triệu chứng đường tiêu hóa như viêm đại tràng mạn tính, viêm ruột, tiêu chảy kéo dài, áp xe quanh hậu môn, rò hậu môn, tắc nghẽn đường tiêu hóa. ${ }^{2}$ Hơn $80 \%$ bệnh nhân CGD có biểu hiện viêm ruột giống với bệnh Crohn. Vì vậy, nhân trường hợp bệnh nhi mắc bệnh CGD, chúng tôi muốn thảo luận cách tiếp cận chẩn đoán và điều trị trường hợp này.

\section{GIỚI THIẸU CA BẸNH}

Bệnh nhân nam, 6 tháng tuổi.

Tiền sử sản khoa: con lần 1 PARA 0000 , đẻ thường, cân nặng khi sinh 3,0 kg. Tiền sử bệnh tật: Khi 17 ngày tuổi trẻ được chẩn đoán và điều trị viêm phế quản phổi và nhiễm khuẩn huyết trong một tháng tại khoa sơ sinh bệnh viện Nhi Trung ương bằng Meronem + Vancomycin 17 ngày sau đó đổi sang Levofloxacin trong 10 
ngày trẻ ổn định và được xuất viện. Khi được 4 tháng tuổi trẻ lại được chẩn đoán áp xe cạnh hậu môn kèm theo tiêu chảy nhiễm khuẩn và viêm tiểu phế quản do virus hợp bào hô hấp (RSV). Đợt bệnh này trẻ được nhập viện và điều trị bằng Ceftriaxol + Metronidazol trong 16 ngày; ra viện trẻ còn đi ngoài 3-4 lần/ ngày phân lỏng, vàng, có nhày. Trẻ được chẩn đoán và điều trị viêm tai giữa lúc 5 tháng tuổi bằng Clarithromycin.

Tiền sử dinh dưỡng: Trẻ được nuôi bằng sữa mẹ hoàn toàn trong 2 tháng đầu, từ tháng thứ 2 trẻ được bổ sung thêm sữa công thức phù hợp với tuổi và chưa được ăn bổ sung.

Tiền sử gia đình: không có ai bị nhiễm khuẩn tái diễn.

Đợt bệnh này, trẻ đi ngoài phân lỏng (Bristol 6), nhày máu, khoảng 10 lần/ngày, kéo dài trên 14 ngày, kèm theo sốt về chiều, nhiệt độ dao động $37,8-39^{\circ} \mathrm{C}$, sốt thất thường, 2 khối cạnh hậu môn sưng đỏ, không chảy dịch, loét miệng.
Trẻ được chẩn đoán tiêu chảy kéo dài, điều trị ngoại trú kháng sinh Cefixime 5 ngày không đỡ. Trẻ nhập viện khoa Tiêu hóa bệnh viện Nhi Trung ương ngày 18/11/2019. Xét nghiệm phân thấy nhiều hồng cầu và bạch cầu, không có vi nấm và kí sinh trùng. Xét nghiệm tổng phân tích tế bào máu ngoại vi: Bạch cầu 33,4 G/L, bạch cầu trung tính 44\%, CRP 54 mg/L. Tổng phân tích nước tiểu bình thường. Cấy nước tiểu, cấy phân không phát hiện vi khuẩn. Chẩn đoán ban đầu: Tiêu chảy kéo dài do nhiễm khuẩn và áp xe cạnh hậu môn. Trẻ được điều trị nhiều loại kháng sinh tĩnh mạch Ciprofloxacin 10 ngày+ Metronidazol 2 ngày sau chuyển sang Fosmycin 4 ngày + Zithromax 5 ngày sau đó là Meronem 9 ngày và Vancomycin 7 ngày do tình trạng lâm sàng và xét nghiệm không cải thiện. Sau 21 ngày điều trị: Trẻ hết sốt, còn đi ngoài 4-5 lần/ngày, Bristol typ 6 , phân vàng nhầy, không máu, xét nghiệm phân bình thường. Xét nghiệm huyết học và sinh hóa của bệnh nhân được trình bày tại bảng 1 .

Bảng 1. Các chỉ số huyết học và sinh hóa của bệnh nhân

\begin{tabular}{cccccccc}
\hline Ngày & $\begin{array}{c}\text { Số lượng } \\
\text { bạch cầu } \\
\text { (G/L) }\end{array}$ & $\begin{array}{c}\text { \% bạch } \\
\text { cầu } \\
\text { trung } \\
\text { tính }\end{array}$ & $\begin{array}{c}\text { Số lượng } \\
\text { tuyệt đối bạch } \\
\text { cầu trung tính } \\
\text { (G/L) }\end{array}$ & $\begin{array}{c}\text { bạch } \\
\text { cầu } \\
\text { lympho }\end{array}$ & $\begin{array}{c}\text { Hemoglobin } \\
\text { (g/L) }\end{array}$ & $\begin{array}{c}\text { Số lượng } \\
\text { tiểu cầu } \\
\text { (G/L) }\end{array}$ & $\begin{array}{c}\text { CRP } \\
\text { (mg/L) }\end{array}$ \\
\hline $17 / 05$ & 18,4 & 46 & 8,5 & 29 & 98 & 395 & 88 \\
\hline $21 / 05$ & 36,3 & 47 & 17,1 & 22 & 96 & 420 & 92 \\
\hline $27 / 05$ & 32 & 52 & 16,6 & 19,3 & 82 & 520 & 50 \\
\hline $31 / 05$ & 25,3 & 39 & 9,9 & 34 & 83 & 532 & 24 \\
\hline $03 / 06$ & 22,6 & 41 & 9,3 & 28 & 82 & 555 & 29 \\
\hline $07 / 06$ & 21 & 44 & 9,2 & 26 & 73 & 475 & 25 \\
\hline $11 / 06$ & 17,5 & 44 & 7,7 & 27 & 103 & 360 & 30 \\
\hline $13 / 06$ & 22,6 & 35 & 7,9 & 36 & 107 & 375 & \\
\hline $29 / 08$ & 30,5 & 34 & 10,4 & 43 & 88 & 493 & 24 \\
\hline $07 / 09$ & 19,4 & 24 & 4,7 & 62 & 92 & 530 & 2,5 \\
\hline
\end{tabular}




\begin{tabular}{cccccccc}
\hline Ngày & $\begin{array}{c}\text { Số lượng } \\
\text { bạch cầu } \\
\text { (G/L) }\end{array}$ & $\begin{array}{c}\text { \% bạch } \\
\text { cầu } \\
\text { trung } \\
\text { tính }\end{array}$ & $\begin{array}{c}\text { Số lượng } \\
\text { tuyê̂t đối bạch } \\
\text { cầu trung tính } \\
\text { (G/L) }\end{array}$ & $\begin{array}{c}\text { \% bạch } \\
\text { cầu } \\
\text { lympho }\end{array}$ & $\begin{array}{c}\text { Hemoglobin } \\
\text { (g/L) }\end{array}$ & $\begin{array}{c}\text { Số lượng } \\
\text { tiểu cầu } \\
\text { (G/L) }\end{array}$ & $\begin{array}{c}\text { CRP } \\
\text { (mg/L) }\end{array}$ \\
\hline $12 / 09$ & 23,2 & 21 & 4,9 & 63 & 102 & 441 & \\
\hline $27 / 10$ & 21,5 & 44 & 9,5 & 37 & 97 & 411 & 16 \\
\hline $18 / 11$ & 33,4 & 41 & 13,7 & 43 & 89 & 349 & 54 \\
\hline $22 / 11$ & 24,2 & 40,4 & 9,8 & 44,6 & 88 & 644 & 20,7 \\
\hline $27 / 11$ & 28,4 & 39,1 & 11,1 & 47,2 & 89 & 523 & 15,5 \\
\hline $02 / 12$ & 37,7 & 51,5 & 19,4 & 36,7 & 81 & 552 & \\
\hline $09 / 12$ & 17,7 & 20,4 & 3,6 & 65,5 & 90 & 560 & \\
\hline
\end{tabular}

Kết quả xét nghiệm huyết học và sinh hóa cho thấy có tình trạng tăng bạch cầu máu ngoại vi liên tục với số lượng tuyệt đối của bạch cầu trung tính tăng hoặc bình thường. Chỉ số CRP luôn cao. Bệnh nhân có thiếu máu mức độ nhẹ có thể do quá trình viêm kéo dài dẫn đến bạch cầu trung tính và đại thực bào không giải phóng sắt để cung cấp nguyên liệu cho tủy xương sinh hồng cầu.

Với tình trạng tiêu chảy kéo dài, trẻ được xét nghiệm Calprotectin phân, kết quả 9,4 $\mu \mathrm{g} / \mathrm{g}$

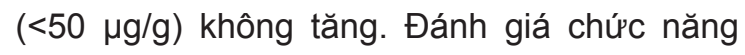
bạch cầu hạt của bệnh nhân bằng test $\mathrm{DHR}$ kết quả quần thể bạch cầu hạt của bệnh nhân

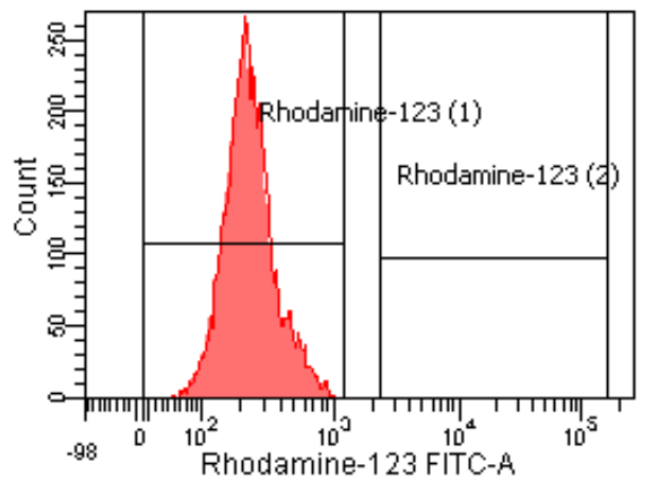

Bệnh nhân

SI 17 giảm chức năng với giá trị Stimulated index (SI) 1,7 (Hình 1). Đánh giá chức năng bạch cầu hạt của bố bệnh nhân bình thường (Hình 2). Đánh giá chức năng bạch cầu hạt của mẹ bệnh nhân có trên $60 \%$ số lượng bạch cầu hạt giảm chức năng (hình 3). Từ kết quả này, nghi ngờ bệnh nhân có đột biến gen lặn trên NST giới tính X, quy định tổng hợp protein gp91 phox. Bệnh nhân được giải trình tự gen thế hệ mới theo phương pháp WES kết quả có đột biến gen CYBB vị trí c.217C>T (p.Arg73Stp). Bệnh nhân được ra viện, điều trị dự phòng nhiễm trùng bằng Biseptol, Fluconazol suốt đời.

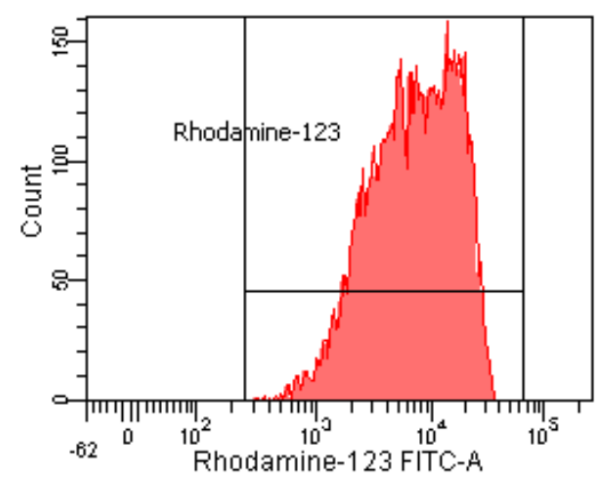

Chứng

SI 67,8

Hình 1. Kết quả DHR test của bệnh nhân 


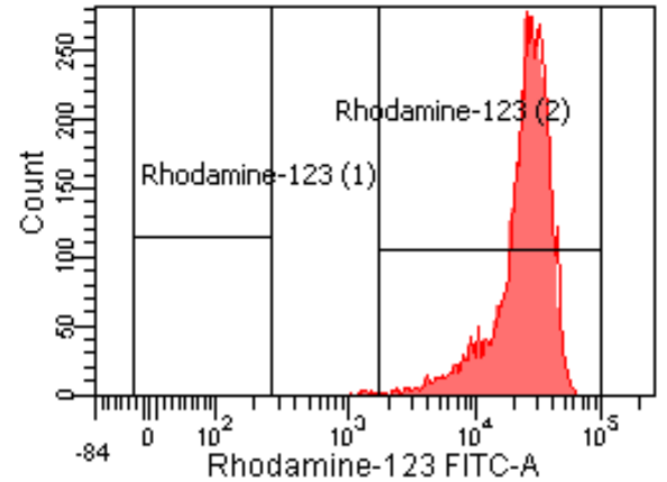

Bố bệnh nhân

$$
\mathrm{SI}=209,8
$$

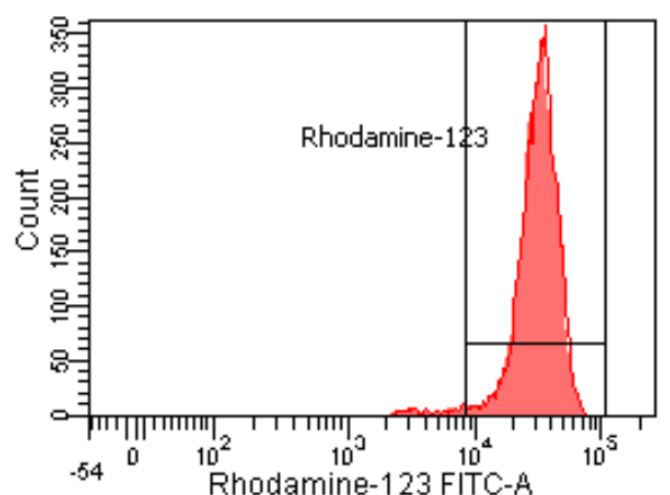

Chứng

$S I=292,1$

Hình 2. Kết quả DHR test của bố bệnh nhân



SI quần thể bạch cầu trung tính (1)=12,1
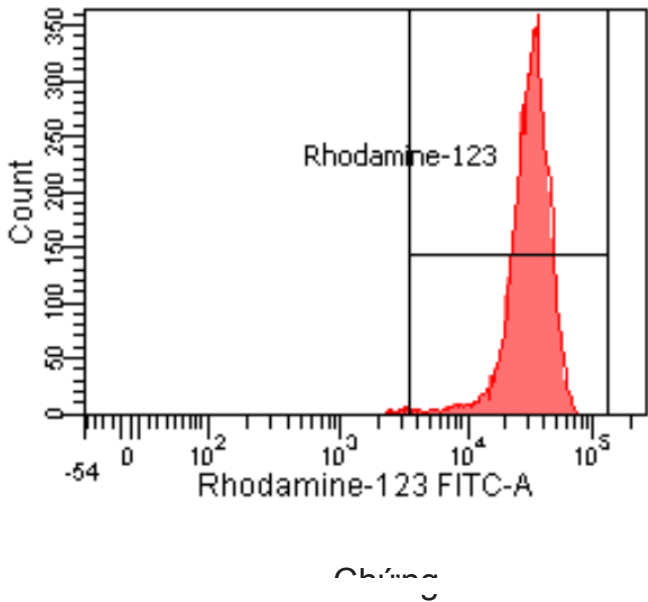

$S I=289,4$

SI quần thể bạch cầu trung tính (2) = 243,0

Hình 3. Kết quả DHR test của mẹ bệnh nhân

\section{BÀN LUÂN}

Bệnh u hạt mạn tính (CGD) là một bệnh suy giảm miễn dịch nguyên phát hiếm gặp gây ra bởi đột biến các gen mã hóa hệ thống enzym oxy hóa Nicotinamide Adenine Dinucleotide Photphate (NADPH). Bạch cầu trung tính và bạch cầu mono có khả năng hóa ứng động, thực bào và khử hạt, nhưng không có khả năng tiêu diệt vi sinh vật do thiếu hụt quá trình sản xuất các gốc oxy hóa tự do ( O2 -).
NADPH oxidase là một enzym 5 cấu phần, bao gồm các protein trong bào tương và các protein trên màng tế bào. Khi không có kích thích, phức hợp enzym oxidase ở trạng thái không hoạt động: gp91 ${ }^{\text {phox }}$ và $\mathrm{p} 22^{\text {phox }}$ nằm trên màng tế bào, gắn với nhau tạo nên cytochrome $\mathrm{b}_{558}$. $\mathrm{p} 67^{\text {phox }}, \mathrm{p} 47^{\text {phox }}, \mathrm{p} 40^{\text {phox }}$ nằm trong bào tương. Khi có kích thích viêm, NADPH oxidase hoạt hóa, phosphoryle hóa tiểu phần p47 phox 
trong bào tương dẫn đến hoạt hóa phức hợp trong bào tương ( $\left.\mathrm{p} 67^{\text {phox }}, \mathrm{p} 40^{\text {phox }}\right)$ và trên màng tế bào (gp91 phox và p22 ${ }^{\text {phox }}$. Phức hợp gắn với protein Rac. Phức hợp hoạt hóa vận chuyển electron từ bào tương vào chất nền phagosome qua màng sinh chất, chuyển điện tử cho $\mathrm{O} 2$ để tạo $\mathrm{O}^{-}$(superoxide). Dạng này không bền, nó chuyển thành $\mathrm{H}_{2} \mathrm{O}_{2}$ tự phát hoặc được xúc tác bởi enzym superoxide dismutase.
Myeloperoxidase xúc tác phản ứng tạo $\mathrm{HClO}$ từ $\mathrm{H}_{2} \mathrm{O}_{2}$ và $\mathrm{Cl}-\mathrm{H}_{2} \mathrm{O}_{2}$ và $\mathrm{HOCl}$ là những tác nhân diệt vi khuẩn mạnh, phá võ̃ và loại bỏ mầm bệnh khỏi các vị trí nhiễm trùng. Sự sản xuất các loại oxy phản ứng (ROS) dẫn đến dòng kali và proton tràn vào phagolysosome, dẫn đến kích hoạt các protease dạng hạt, bao gồm elastase và cathepsin $\mathrm{G}$. Các protease này chịu trách nhiệm tiêu diệt các vi sinh vật ăn vào ${ }^{3}$ (Hình 4).

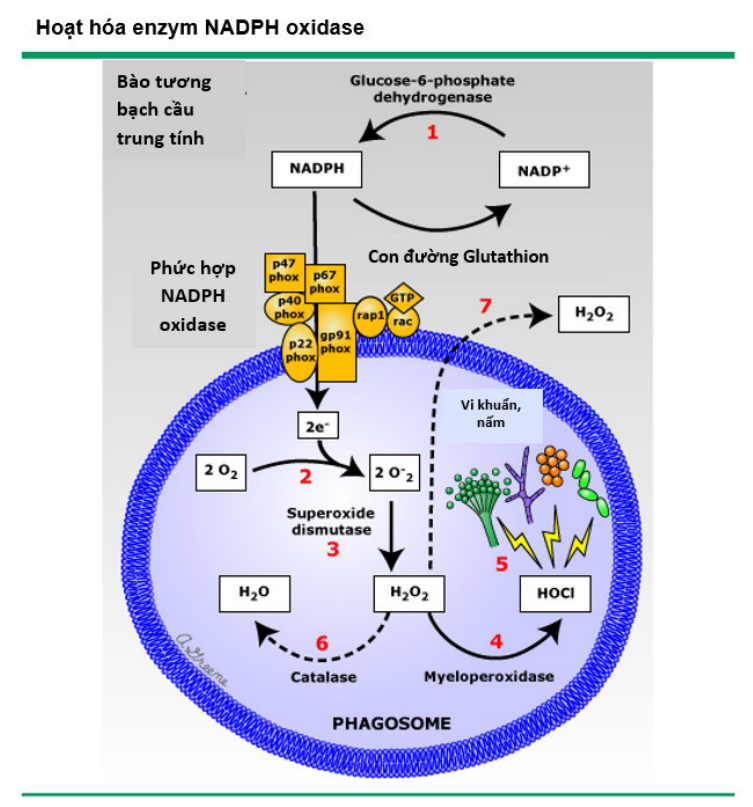

\section{Hình 4. Cơ chế hoạt hóa enzym NADPH oxidase ${ }^{4}$}

Biểu hiện lâm sàng của bệnh CGD gồm nhiễm trùng, u hạt. Bệnh nhân có thể bị nhiễm trùng tái diễn hoặc nhiễm trùng nặng do vi khuẩn hoặc nấm; phổ biến là viêm phổi tái diễn, viêm hạch bạch huyết, áp xe gan, viêm mô tế bào, viêm tủy xương ở nhiều vị trí, hoặc nhiễm trùng huyết do Salmonella, Burkholderia cepacia hoặc Candida. Tần suất và mức độ nhiễm trùng không giảm khi trẻ trên 10 tuổi, mặc dù hệ miễn dịch trưởng thành hơn so với mười năm đầu đời. Tác nhân gây bệnh phổ biến nhất là Streptococcus aureus. Các sinh vật khác thường gây nhiễm trùng bao gồm Serratia marcescens, Burkholderia cepacia, Aspergillus, Candida albicans, Nocardia và
Salmonella. Người bệnh có thể tăng tính nhạy cảm với Mycobacterium, bao gồm cả vắc-xin BCG. Loét miệng tái diễn thường gặp ở CGD và đặc biệt phổ biến ở người mang gen trên NST X. Trường hợp bệnh nhân báo cáo trong bài này có nhiều đợt nhiễm khuẩn nặng kể từ giai đoạn sơ sinh gồm một đợt nhiễm khuẩn huyết, một đợt viêm tai và một đợt viêm phế quản phổi, tiêu chảy nhiễm khuẩn kéo dài, áp xe cạnh hậu môn, viêm hạch, loét miệng.

Bệnh nhân CGD dễ hình thành u hạt, có thể ảnh hưởng đến bất kỳ tạng rỗng, đặc biệt đường tiêu hóa và đường sinh dục. Võng mạc, gan, phổi và xương, cũng có thể bị ảnh hưởng bởi u hạt. $U$ hạt gây tắc nghẽn môn vị, bàng 
quang hoặc tắc niệu quản, hoặc rò trực tràng và viêm đại tràng hạt giống như bệnh Crohn. Các biểu hiện lâm sàng tiêu hóa của CGD bao gồm đau bụng, tiêu chảy, viêm đại tràng, viêm ruột, hẹp, rò, và tắc nghẽn.

Chẩn đoán xác định bệnh có thể dựa vào test $\mathrm{DHR}$ và hoặc xét nghiệm gen. Test DHR được chấp nhận trên toàn thế giới là test sàng lọc CGD. Nguyên lý xét nghiệm dựa trên nguyên tắc bạch cầu trung tính được kích thích bởi Phorbol-12-Myristate-13 Acetat để sản xuất các dạng oxy phản ứng (ROS: $\mathrm{O}_{2}^{-}, \mathrm{H}_{2} \mathrm{O}_{2}$ ). Dihidrorhodamine (không màu) bị oxy hóa thành Rhodamine-123 (màu xanh) dưới tác dụng của các dạng oxy phản ứng. Rhodamine-123 có màu xanh, gắn với màng và bào tương của tế bào được xác định bằng phương pháp Flow cytometry (bước sóng 488 $\mathrm{nm}$ ). Tính hệ số kích thích (SI) và hình dạng đồ thị có thể chẩn đoán các trường hợp bệnh và người mang gen (liên kết NST X) nhưng có thể không phát hiện được người mang gen lặn trên NST thường vì chỉ cần 1 alen bình thường cũng đủ để thực hiện chức năng. Về xét nghiệm gen, hiện nay các nghiên cứu đã xác định được 5 đột biến gen gây bệnh. Một gen trên NST giới tính $X$ là cytochrome b-245, tiểu đơn vị beta (CYBB) mã hóa protein gp91 ${ }^{\text {phox }}$. Đột biến này chiếm 65-70\% trường hợp CGD ở Mỹ và châu Âu. ${ }^{5}$ CGD do đột biến gen trên NST $X$ có $x u$ hướng khởi phát sớm hơn và nặng hơn so với CGD do lặn trên NST thường, tương đồng với ca bệnh được miêu tả. Bốn gen trên nhiễm sắc thể thường. Một là, gen cytochrome b-245, tiểu đơn vị alpha (CYBA) nằm ở NST 16q24 mã hóa protein p22 $2^{\text {phox }}$ chiếm ít hơn $5 \%$ số trường hợp CGD. ${ }^{5}$ Hai là, gen NCF1 nằm trên $7 q 11.23$ mã hóa p47 phox. Đột biến này chiếm gần $25 \%$ số trường hơn CGD ở Mỹ. Gần $80 \%$ đột biến protein $\mathrm{p} 47^{\text {phox }}$ là đột biến mất bazơ nitơ GT (guanine-thymine) ở exon $2 .{ }^{6}$ Ba là, gen NCF2 nằm trên NST 1q25 mã hóa p67phox . Chiếm ít hơn $5 \%$ số trường hợp. ${ }^{7}$ Bốn là, gen NCF4 nằm trên NST 22a13.1 mã hóa protein $\mathrm{p} 40^{\text {phox }}$ . Bệnh nhân mang đột biến gen NCF4 có bệnh lý hô hấp mức độ nhẹ nhưng bệnh lý ruột viêm (IBD) nặng và có test DHR bình thường. ${ }^{8}$

Điều trị dựa trên nguyên tắc dự phòng kháng sinh và kháng nấm suốt đời, phát hiện sớm và điều trị tích cực nhiễm trùng, điều trị biến chứng. ${ }^{9}$ Điều trị dự phòng nhiễm khuẩn suốt đời với Trimethoprim-Sulfamethoxazole (TMP-SMX) ( $5 \mathrm{mg} / \mathrm{kg} / \mathrm{ngày}$ lên đến tối đa $320 \mathrm{mg}$, dựa trên thành phần trimethoprim, dùng đường uống hai lần mỗi ngày). Một số trung tâm sử dụng liều dùng một lần mỗi ngày để tăng cường tuân thủ điều trị. Các lựa chọn thay thế cho bệnh nhân dị ứng với thuốc sulfonamid bao gồm trimethoprim mà không dùng sulfamethoxazole, penicillin ổn định betalactamase (ví dụ, dicloxacillin), cephalosporin hoặc fluoroquinolones. Điều trị dự phòng TMPSMX không dẫn đến sự gia tăng nhiễm nấm. Itraconazole ( $5 \mathrm{mg} / \mathrm{kg} / \mathrm{ngày}$ uống một lần mỗi ngày, liều tối đa 200 mg) là liệu pháp được khuyến cáo để điều trị dự phòng kháng nấm suốt đời. Nếu nấm kháng itraconazole, hầu hết đáp ứng với voriconazole hoặc posaconazole. Các tác dụng không mong muốn của Intraconazole bao gồm: tăng men gan, bệnh lý thần kinh ngoại vi, hội chứng Steven-Johnson. Tuy nhiên Intraconazole dung nạp tốt ở bệnh nhân CGD và có hiệu quả làm giảm tỷ lệ nhiễm nấm. Cần xét nghiệm men gan trước điều trị và định kỳ mỗi 6 tháng sau điều trị. Dự phòng kháng sinh được khuyến nghị cho tất cả các thủ thuật xâm lấn, bao gồm: nội soi đại tràng, nội soi đường tiêu hóa trên, nội soi phế quản, sinh thiết gan, sinh thiết phổi. Dự phòng bằng Ciprofloxacin (và thêm Metronidazole nếu liên quan đến vùng dưới cơ hoành) nên bắt đầu trước khi làm thủ thuật và tiếp tục ít nhất 24 giờ sau. Về vấn 
đề tiêm chủng, vắc-xin vi khuẩn sống nên tránh (ví dụ Salmonella, BCG..). Vắc-xin virus sống vẫn được khuyến nghị. Nên tiêm phòng vacxin cúm hàng năm cho tất cả bệnh nhân CGD. Tất cả các vắc-xin bất hoạt hoặc tiểu đơn vị được khuyến nghị theo cùng một lịch trình như trẻ bình thường. Bệnh nhân CGD có sốt cần điều trị sớm bằng kháng sinh đường tĩnh mạch phù hợp. Điều này có thể gia tăng tỷ lệ điều trị kháng sinh không đúng (nhiễm virus) hoặc lạm dụng kháng sinh, tuy nhiên, đây là tiếp cận an toàn đối với bệnh nhân CGD. Bệnh nhân CGD cần điều trị với kháng sinh liều cao, dài ngày, phối hợp kháng sinh so với người bình thường. Ciprofloxacin là thuốc ưu tiên sử dụng vì thuốc có khả năng thấm vào nội bào. Lợi ích khi sử dụng Ciprofloxacin lớn hơn nguy cơ bệnh khớp động vật non. Liều Ciprofloxacin: Trẻ em $7,5 \mathrm{mg} / \mathrm{kg} / 12$ giờ; người lớn 500-750mg/12h. Teicoplanin và Ciprofloxacin là là kháng sinh đường tĩnh mạch được lựa chọn đầu tiên trong điều trị nhiễm khuẩn huyết nặng. Thêm Metronidazole nếu nghi ngờ nhiễm trùng dưới cơ hoành. Nếu phân lập được Staphylococcus, sử dụng Flucloxacillin, Fucidin hoặc một loại kháng sinh chống tụ cầu khác, ví dụ Clindamycin, Clarithromycin. Luôn phân biệt nhiễm khuẩn với nhiễm nấm, nhất là khi điều trị nhiễm khuẩn bằng kháng sinh 7-10 ngày không đáp ứng. Điều trị biến chứng viêm đại tràng ở bệnh nhân CGD bằng 5-ASA (ví dụ: Sulphasalazine và Mesalazine) là lựa chọn đầu tiên. Steroid và các chất ức chế miễn dịch khác như Azathioprine, có thể được chỉ định khi 5-ASA thất bại trong đạt lui bệnh hoặc duy trì lui bệnh. Tuy nhiên, những chất ức chế miễn dịch nên được sử dụng một cách thận trọng và thảo luận với chuyên gia, đặc biệt trên bệnh nhân nhiễm khuẩn tái diễn hoặc tiền sử có nhiễm nấm. Khi có u hạt làm tắc nghẽn ống tiêu hoá có thể sử dụng steroid khi đã loại trừ các nguyên nhân nhiễm khuẩn.
Trong những năm vừa qua, nhờ những tiến bộ trong chẩn đoán và điều trị dự phòng kháng sinh, khả năng sống sót của bệnh nhân CGD đã được cải thiện đáng kể. ${ }^{10,11}$ Bệnh nhân CGD có tuổi thọ ít nhất 40 tuổi. Nhiễm nấm đường hô hấp (chủ yếu là các loài Aspergillus) vẫn là nguyên nhân gây tử vong hàng đầu. ${ }^{11}$ Tỷ lệ sống sót ở tuổi 20 được ghi nhận ở một số nghiên cứu được công bố là $73-87 \%$ với thời gian sống thêm trung bình là 18 năm đối với bệnh nhân CGD có đột biến gen trên NST X, và 36 năm nếu CGD do gen trên NST thường. ${ }^{12,13}$ Một nghiên cứu trên 287 bệnh nhân CGD đã đưa ra kết luận số lượng oxy phản ứng (ROS) còn lại liên quan chặt chẽ đến thời gian sống sót và các bệnh nhân có đột biến gen p47 phox và 309 axit amin đầu tiên của gen gp91 ${ }^{\text {phox }}$ có số lượng oxy phản ứng còn lại cao hơn. ${ }^{10}$ Để nâng cao chất lượng cuộc sống của bệnh nhân cần phối hợp điều trị nhiễm trùng với điều trị triệu chứng các cơ quan bị bệnh (ví dụ: tình trạng viêm ruột). Liệu pháp ghép tế bào gốc đang được nghiên cứu có triển vọng điều trị triệt để bệnh.

\section{KÊTT LUẬN}

Nên đánh giá chức năng bạch cầu hạt ở những bệnh nhân bị nhiễm trùng tái diễn và số lượng bạch cầu máu tăng cao, đáp ứng kém với liệu pháp điều trị kháng sinh. Cần chẩn đoán phân biệt với bệnh CGD ở các bệnh nhân có các biểu hiện tiêu hóa như tiêu chảy kéo dài, rò hậu môn, áp xe cạnh hậu môn được chẩn đoán bệnh ruột viêm.

\section{Lò̀i cảm ơn}

Chúng tôi xin gửi lời cảm ơn chân thành đến cha mẹ bệnh nhân, khoa Tiêu hóa - Bệnh viện Nhi Trung ương đã hợp tác, giúp đỡ, tạo điều kiện để chúng tôi thực hiện báo cáo ca bệnh này. 


\section{TÀI LIẸU THAM KHẢO}

1. Chronic granulomatous disease: Clinical, molecular, and therapeutic aspects - Chiriaco 2016 - Pediatric Allergy and Immunology - Wiley Online Library. Accessed December 12, 2019. https://onlinelibrary.wiley.com/doi/pdf/10.1111/ pai.12527.

2. Marciano BE, Rosenzweig SD, Kleiner DE, Anderson VL, Darnell DN, Anaya-O'Brien S, Hilligoss DM, Malech $\mathrm{HL}$, Gallin JI, Holland SM. Gastrointestinal involvement in chronic granulomatous disease. Pediatrics. 2004;114(2):462-468.doi:10.1542/ peds.114.2.462.

3. Reeves EP, Lu H, Jacobs HL, Messina CGM, Bolsover S, Gabella G, Potma EO, Warley A, Roes J, Segal AW. Killing activity of neutrophils is mediated through activation of proteases by K+ flux. Nature. 2002;416(6878):291-297. doi:10.1038/416291a.

4. Chronic granulomatous disease: Pathogenesis, clinical manifestations, and diagnosis UpToDate. Accessed December 12,2019.https:// www.uptodate.com/contents/chronic-granulomatous-disease-pathogenesis-clinical-manifestations-and-diagnosis?search=chronic $\% 20$ granulomatous\%20disease\&source=search_result\&selectedTitle=1 139\&usage_type=default\&display_rank=1.

5. Roos D, Kuhns DB, Maddalena A, Roesler J, Lopez JA, Ariga T, Avcin T, de Boer M, Bustamante J, Condino-Neto A, Di Matteo G, He J, Hill HR, Holland SM, Kannengiesser C, Köker MY, Kondratenko I, van Leeuwen K, Malech HL, Marodi L, Nunoi H, Stasia M-J, Ventura AM, Witwer CT, Wolach B, Gallin JI. Hematologically important mutations: X-linked chronic granulomatous disease (third update). Blood Cells Mol Dis. 2010;45(3):246-265. doi:10.1016/j.bcmd.2010.07.012.
6. Dekker J, de Boer M, Roos D. Genescan method for the recognition of carriers and patients with p47(phox)-deficient autosomal recessive chronic granulomatous disease. Exp Hematol. 2001;29(11):1319-1325. doi:10.1016/ s0301-472x(01)00731-7.

7. Roos D, Kuhns DB, Maddalena A, Bustamante J, Kannengiesser C, de Boer M, van Leeuwen K, Köker MY, Wolach B, Roesler J, Malech HL, Holland SM, Gallin JI, Stasia M-J. Hematologically important mutations: the autosomal recessive forms of chronic granulomatous disease (second update). Blood Cells Mol Dis. 2010;44(4):291-299. doi:10.1016/j.bcmd.2010.01.009.

8. Matute JD, Arias AA, Wright NAM, Wrobel I, Waterhouse CCM, Li XJ, Marchal CC, Stull ND, Lewis DB, Steele M, Kellner JD, Yu W, Meroueh SO, Nauseef WM, Dinauer MC. A new genetic subgroup of chronic granulomatous disease with autosomal recessive mutations in $\mathrm{p} 40$ phox and selective defects in neutrophil NADPH oxidase activity. Blood. 2009;114(15):33093315. doi:10.1182/blood-2009-07-231498.

9. Seger RA. Modern management of chronic granulomatous disease. Br J Haematol. 2008;140(3):255-266.doi:10.1111/j.13652141.2007.06880.x.

10. Kuhns DB, Alvord WG, Heller T, Feld JJ, Pike KM, Marciano BE, Uzel G, DeRavin SS, Priel DAL, Soule BP, Zarember KA, Malech $\mathrm{HL}$, Holland SM, Gallin JI. Residual NADPH oxidase and survival in chronic granulomatous disease. N Engl J Med. 2010;363(27):26002610. doi:10.1056/NEJMoa1007097.

11. Marciano BE, Spalding C, Fitzgerald A, Mann D, Brown T, Osgood S, Yockey L, Darnell DN, Barnhart L, Daub J, Boris L, Rump AP, Anderson VL, Haney C, Kuhns DB, 
Rosenzweig SD, Kelly C, Zelazny A, Mason T, DeRavin SS, Kang E, Gallin JI, Malech HL, Olivier KN, Uzel G, Freeman AF, Heller T, Zerbe CS, Holland SM. Common severe infections in chronic granulomatous disease. Clin Infect Dis. 2015;60(8):1176-1183. doi:10.1093/cid/ciu1154.

12. Kobayashi S, Murayama S, Takanashi S, Takahashi K, Miyatsuka S, Fujita T, Ichinohe $\mathrm{S}$, Koike $\mathrm{Y}$, Kohagizawa T, Mori H, Deguchi $\mathrm{Y}$, Higuchi K, Wakasugi H, Sato T, Wada Y, Nagata M, Okabe N, Tatsuzawa O. Clinical features and prognoses of 23 patients with chronic granulomatous disease followed for 21 years by a single hospital in Japan. Eur $J$ Pediatr. 2008;167(12):1389-1394. doi:10.1007/s00431008-0680-7.

13. Wolach B, Gavrieli R, de Boer M, Gottesman G, Ben-Ari J, Rottem M, Schlesinger Y, Grisaru-Soen G, Etzioni A, Roos D. Chronic granulomatous disease in Israel: clinical, functional and molecular studies of 38 patients. Clin Immunol. 2008;129(1):103-114. doi:10.1016/j. clim.2008.06.012.

\section{Summary}

\section{CHRONIC GRANULOMATOUS DISEASE: A CASE REVIEW}

Chronic granulomatous disease (Chronic Granulomatous Disease CGD) is a rare hereditary disease, characterized by recurrent and severe bacterial or fungal infections, a result of impaired phagocytic function neutrophils and macrophages. We described a case of CGD presented with clinical and paraclinical symptoms, a pattern often seen in Crohn's patients, such as persistent diarrhea and perianal abscess, and a history of repeated severe infections was recorded. Patients consistently have a high peripheral leukocyte count. DHR low activity was confirmed by a genetic sequencing assay detecting a mutation of the CYBB gene c.217C>T (pArg73Stp) on chromosome $X$. Protein gp91phox is an essential component of enzymeNADPH oxidase. The patient was treated with intravenous antibiotics, followed by lifelong antibacterial and antifungal prophylaxis. CGD is a rare and challenging case to diagnose. This patient's symptoms resemble other infectious diseases, especially Crohn's disease in Gastroenterology, so it is necessary to distinguish and diagnose in order to have an appropriate treatment plan.

Keywords: chronic granulomatous disease, (CGD) Crohn disease, persistent infection. 